\title{
Anti -Microbial effect of three essential oils in treating Upper respiratory tract Infection via vapours generated by Pressurized steam chamber (PSC)
}

\author{
Research Article
}

\section{Jegannathan Ganesan1, Vighnesh Adikesavan², Srimathi Devi Jegannathan 3*}

1. Director, 2. Deputy General Manager, 3. Project Manager,

Ideal Flow Control Private Limited, Mogappair Industrial Estate, Tamil Nadu, Chennai, India.

\begin{abstract}
Disinfection tunnel (DT) or sanitization tunnel used for disinfecting the persons by spraying with appropriately atomized virucide spray, Direct inhalation or spraying of disinfectants on people with chemical element and different toxicant chemicals may lead to eye and skin irritation and cause numerous allergic disorders. So this obstacle was overcome by Ideal flow control private limited by designing the Pressurized Steam Chamber (PSC) in which Natural oils was mixed in an emulsifier solution, and induced along with steam through multiple nozzles within the chamber, so that persons could get disinfected the entire body. Anti-microbial efficacy of our three essentials oils were determined by standard method, ISO 4833-1:2013 by collecting sample through walk in/walk out chamber protocol. Our present study report of MSME (ministry of micro, small and medium enterprises) and SGS Chennai, reveals that in phytotherapeutic oils initial microbial load are found to be $<1 \mathrm{CFU} / \mathrm{mL}$, in emulsifier and in formulation (water + emulsifier + natural oils) the presence of bacterial colonies found to be 470000 $\mathrm{CFU} / \mathrm{mL}$ and $20000000 \mathrm{CFU} / \mathrm{mL}$ whereas, the distillate collected from essential oils at $65^{\circ} \mathrm{c}$ shows the absence of microbial load. Further swab analysis report of 8 individuals states that samples (hand swab and surface swab) collected for the estimation of Total plate Count showed that there is a reduction in microbial load when exposed to the Steam generated by Pressurized Steam Chamber (PSC) at both the time intervals, 20 and 40 seconds. These findings confirm that three essential phytotherapeutic oils combined with steam have some potent activity against emerging disease.
\end{abstract}

Key Words: Disinfection chamber, Phytotherapeutic oils, Steam.

\section{Introduction}

An outbreak of COVID-19, posing extreme threats to the human lives which were caused by Corona virus, a family of SARS, which is contagious. In 2003 other human corona virus was identified such as severe acute respiratory syndrome (SARS) and Middle East respiratory syndrome (MERS). In 2019, a new corona virus was evolved as corona virus 2 (SARS-CoV-2) causes a disease outbreak that originated in China. In the present scenario, due to a corona virus pandemic, WHO has declared the outbreak in Public Health Emergency of International Concern on 30 January 2020, and a pandemic on 11 March 2020, with the certain preventive measures like Social Distancing, Frequent Hand washing, wearing personal protective gadgets (face mask, face shield, gloves ) and through another effective method called disinfectant tunnels which is potentially effective in the context of a

\section{* Corresponding Author:}

\section{Srimathi Devi Jegannathan}

Ideal Flow Control Private Limited

Mogappair Industrial Estate

Mogappair West, Chennai, Tamil Nadu. India.

Email Id: srimathidevi.j@gmail.com prolonged pandemic of COVID-19. An ideal disinfectant for spraying in these tunnels should be nonvolatile, require less contact time, be harmless to mucous membranes and skin, and have virucidal and bactericidal activity. These disinfectants can destroy the outer envelope of the virus, only if allowed for a recommended concentration with a contact period of more than $60 \mathrm{sec}$. There have been a lot of confidencebuilding measures rapidly initiated in the current COVID-19 pandemic. Foremost among these measures, Stem chamber, a traditional technology which would be an effective alternative technology used as a purifier for an upcoming era. The power consumption, dosing tank, photo sensor, size of chamber, operating time, material of construction - Stainless steel fabrication, SS pipe, SS nozzles in portable structures are customized based upon the source of erection ( PSC- 6 : Humans, PSC-V-20: Two wheelers and cars, PSC-BL-25: Buses and trains, PSC-M-30: Metro trains, PSC-T-90: Trains).

\section{Review of literature}

Dr. Dilip Pawar leading study investigator in Seven Hills Hospital, Mumbai conducted the study using steam by including two groups, group 1: 105 asymptomatic, mild, and moderate patients steam was given twice a day by the nasal route and for group 2: symptomatic patients and health coworkers steam was administered by nasal and oral route every 3 hours for 5 
minutes. From an above- mentioned observational study result reveals that in group 1 patients didn't show any sign of progression to Covid-19 symptoms after 14 days to 2 months. In group 2 mild symptoms regressed in 3 days to normal and in moderate symptoms, it took 7 to 10 days to return to normal. Further, he concluded that steam temperature (70 to 80 degrees Celsius) would be unstable for the virus so that it will effectively kill SARS - Cov-2, and can be permitted as an adjunct to social distancing, sanitizers, masks, and PPE for effective treatment of covid-19 infection.

Due to its volatility, this essential oil could reach rapidly in an upper respiratory tract, lower respiratory tract by inhalation. Gyorghi Horwath et al suggested that anti- viral activity of eucalyptus oil, tea grass oil, was tested by RT-PCR, Virus inhibition assay and the result reveals that, these two oils are effective virucidal agent by inhibiting the viral genome replication of HIV virus, Polio virus, dengue virus, Coxachine B group virus.

Ong G.H., et al suggested that Antiviral effect of crude aqueous extracts of Neem leaves and Neem bark (Azadirachta Indica) were studied by in-vitro virus inhibition assay and the result reveals that Antiviral activity of Neem bark extract had antiviral activity at the concentration of $5.6 \mathrm{mg} / \mathrm{ml}$.

In our present study other factors such as stability, exposure time, chemical composition, and concentration of essential oil in vapor phase incubation temperature, were tested through the reduction in bacterial count assay by Ministry of Micro, Small, and Medium Enterprises (MSME) and Société Générale de Surveillance (SGS) Chennai. In our further research work, an anti-viral efficacy of our compound was evaluated for baseline studies and the results are in progress for the validation study of the clinical trial with ethical committee approval.

\section{Fig 1: Flow chart of Pressurized steam Chamber}

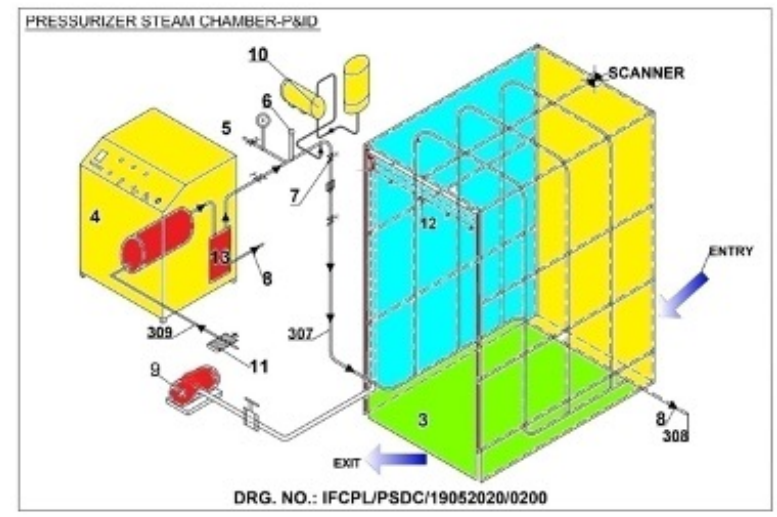

\section{Materials required}

1.Electrical Boiler - 33KW.

2.Portable water.

3.Natural Extracts: Neem Oil, Eucalyptus Oil \&

Turmeric Oil along with emulsifier.

4. Dosing pump - 01 No

5. Water charging Pump - 01 No

\section{Dosing formulation}

- Turmeric oil - $4 \mathrm{ml}$
- Eucalyptus oil - $8 \mathrm{ml}$

- Neem oil - $20 \mathrm{ml}$

These oils are mixed in $4 \mathrm{~L}$ of water with an $8 \mathrm{ml}$ emulsifier and dosed at $5 \mathrm{ml} / \mathrm{min}$ along with pressurized steam at ambient temperature at $65^{\circ} \mathrm{C}$ with humidity above $90 \%$.

\section{Role of steam}

- Diaphoresis (sweating), Vasodilatory, analgesic, antispasmodic, sedative, anti-pyretic, expectorant effect.

\section{Working Principle}

When a person walks near the chamber, the motion sensor detects before 2 to 3 feet and the sensor sends the signal to solenoid valves where the steam is produced at 140 to $150{ }^{\circ} \mathrm{C}$ Temperature and Pressure around 2.5 to $3 \mathrm{Kg} / \mathrm{Cm}^{2}$ and stored at steam accumulator. Once, the above- mentioned criteria were fulfilled it starts opening the Steam, pass through PRV, and reduces the outlet pressure to 1.5 to $2 \mathrm{Kg} / \mathrm{cm} 2$ and temperature around to 60 to $65^{\circ} \mathrm{C}$, dosing pump starts dosing the natural extract at the required PPM and sprayed through multiple nozzles within the chamber.

\section{Safety Features}

We use a safety valve in the main steam line which relieves during excess pressure as safety of the steam generator. Then a High Temperature \& Pressure sensor, High \& low water level sensor are used for Safety, 2 Pressure Gauges and 2 temperature Gauges are also used at Inlet and Outlet of the steam piping. The steam chamber is equipped with safety futures like temperature sensor which has an automatic cut off/on when the steam temperature exceeds $70^{\circ}-75^{\circ}$. Condensate water drops are being collected at the bottom of the drain pipe and by using Steam Trap valve the water drains out from system.

\section{Figure 2: Flow chart of the working principle}

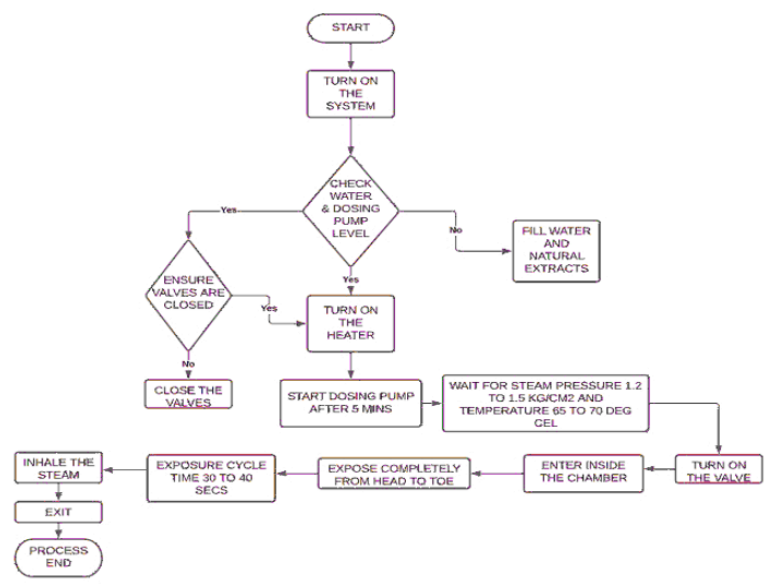

\section{Methodology}

Estimation of microbial load in the natural oil, emulsifier, formulation and distillate

Initial microbial load in the natural oils, emulsifier, formulation, and distillate at $65^{\circ} \mathrm{C}$ was determined through total plate count by collecting the 
swab samples in sterile containers before and after the disinfection at two intervals of 20 and 40 seconds for a period of three days to assess the efficacy of the steam chamber, PSC. A total of 55 swabs were taken along with control, each day to minimize the error. The swab sampling was done based on the standard method, ISO 18593:2014. The collected swab samples were placed inside a sampling box at $2-8^{\circ} \mathrm{C}$. After the completion of each day trial, the samples were brought to the SGS Chennai laboratory along with the travel controls and tested for the Total Plate Count to find out the microbial load by following the standard method, ISO4833-1:2013 (horizontal method for enumeration of microorganisms that can grow and form colonies in a solid medium after aerobic incubation at $30{ }^{\circ} \mathrm{C}$ for $72 \mathrm{hrs}$ ).

Table1: Chemical composition of essential oil in emulsifier and water

\begin{tabular}{|c|c|c|c|c|}
\hline \multicolumn{5}{|c|}{ emuisiner and water } \\
\hline $\begin{array}{l}\text { SI. } \\
\text { No. }\end{array}$ & Natural oil & $\begin{array}{l}\text { Water } \\
\text { ( L) }\end{array}$ & $\begin{array}{c}\text { Emulsifier } \\
\text { ( L) }\end{array}$ & $\begin{array}{c}\text { Quantity } \\
\text { of } \\
\text { natural } \\
\text { oil added } \\
\text { (L) }\end{array}$ \\
\hline 1 & Neem oil & \multirow{3}{*}{7} & \multirow{3}{*}{0.05} & 0.04 \\
\hline 2 & Eucalyptus oil & & & 0.015 \\
\hline 3 & Turmeric oil & & & 0.02 \\
\hline
\end{tabular}

\section{Results}

Table 2: Initial microbial load in the natural oil, emulsifier, formulation, and distillate

\begin{tabular}{c|c|c|c|c|}
$\begin{array}{c}\text { S . } \\
\text { No. }\end{array}$ & Sample name & $\begin{array}{c}\text { Para } \\
\text { meter }\end{array}$ & Method & Result \\
\hline 1 & Neem oil & TPC & ISO4833-1:2013 & $<1$ \\
\hline 2 & Turmeric oil & TPC & ISO4833-1:2013 & $<1$ \\
\hline 3 & Eucalyptus oil & TPC & ISO4833-1:2013 & $<1$ \\
\hline 4 & Emulsifier & TPC & ISO4833-1:2013 & 47000 \\
\hline 5 & Formulation & TPC & ISO4833-1:2013 & 20000000 \\
6 & Distillate at 65 & TPC & ISO4833-1:2013 & $<1$ \\
\hline
\end{tabular}

\section{TPC: Total plate count}

The initial microbial load in the natural oils, viz. Neem oil, Eucalyptus oil, and Turmeric oil are found to be $<1 \mathrm{CFU} / \mathrm{mL}$. Whereas, the emulsifier and the formulation (water + emulsifier + natural oils) used in the PSDC system showed the presence of bacterial colonies of $470000 \mathrm{CFU} / \mathrm{mL}$ and $20000000 \mathrm{CFU} /$ $\mathrm{mL}$, respectively. The distillate collected at $65^{\circ} \mathrm{C}$ showed the absence of microbial load $(<1 \mathrm{CFU} / \mathrm{mL})$.

Table 3: Control swab result

\begin{tabular}{|c|c|c|c|}
\hline SI. NO. & DAY & BATCH N O. & RESULT \\
\hline 1 & DAY 1 & $13.7 .2020-\mathrm{T} 1$ & $<10 \mathrm{CFU} / \mathrm{SWAB}$ \\
\hline 2 & DAY-2 & $14.7 .2020-\mathrm{T} 2$ & $<10 \mathrm{CFU} / \mathrm{SWAB}$ \\
\hline 3 & DAY-3 & $15.7 .2020-\mathrm{T} 3$ & $<10 \mathrm{CFU} / \mathrm{SWAB}$ \\
\hline
\end{tabular}

Table 4: Day 1 (13.07.2020) Microbial load in the swab samples and the percentage reduction

\begin{tabular}{|c|c|c|c|c|c|c|}
\hline \multirow{3}{*}{ S . NO. } & \multirow{3}{*}{ Type of Swab } & \multicolumn{4}{|c|}{ Microbial load (Before and after disinfection, CFU/swab) } & \multirow{3}{*}{$\begin{array}{l}\text { Microbial load } \\
\text { Reduction \% }\end{array}$} \\
\hline & & \multicolumn{2}{|c|}{$20 \mathrm{sec}$} & \multicolumn{2}{|c|}{$40 \mathrm{sec}$} & \\
\hline & & Before & After & Before & After & \\
\hline 1 & Hand swab & 230 & - & - & - & \multirow{2}{*}{34.78} \\
\hline 2 & Hand swab & - & 150 & - & - & \\
\hline 3 & Hand swab & 170 & - & - & - & \multirow{2}{*}{58.82} \\
\hline 4 & Hand swab & - & 70 & - & - & \\
\hline 5 & Hand swab & - & - & 1100 & - & \multirow{2}{*}{50.00} \\
\hline 6 & Hand swab & - & - & - & 550 & \\
\hline 7 & Hand swab & - & - & 130 & - & \multirow{2}{*}{30.77} \\
\hline 8 & Hand swab & - & - & - & 90 & \\
\hline 9 & Hand swab & 150 & - & - & - & \multirow{2}{*}{40.0} \\
\hline 10 & Hand swab & - & 90 & - & - & \\
\hline 11 & Surface swab & 80 & - & - & - & \multirow{2}{*}{100} \\
\hline 12 & Surface swab & - & $<10$ & - & - & \\
\hline 13 & Surface swab & 150 & - & - & - & \multirow{2}{*}{46.67} \\
\hline 14 & Surface swab & - & 80 & - & - & \\
\hline 15 & Surface swab & - & - & 660 & - & \multirow{2}{*}{51.52} \\
\hline 16 & Surface swab & - & - & - & 320 & \\
\hline 17 & Surface swab & - & - & 110 & - & \multirow{2}{*}{100} \\
\hline 18 & Surface swab & - & - & - & $<10$ & \\
\hline
\end{tabular}

Table 5: Day 2 - Microbial load in the swab samples and the percentage reduction

\begin{tabular}{|c|c|c|c|c|c|c|}
\hline \multirow{3}{*}{ S . NO. } & \multirow{3}{*}{ Type of Swab } & \multicolumn{4}{|c|}{ Microbial load (Before and after disinfection, CFU/swab) } & \multirow{3}{*}{$\begin{array}{l}\text { Microbial load } \\
\text { Reduction \% }\end{array}$} \\
\hline & & \multicolumn{2}{|c|}{20 sec } & \multicolumn{2}{|c|}{$40 \mathrm{sec}$} & \\
\hline & & Before & After & Before & After & \\
\hline 1 & Hand swab & 610 & - & - & - & 78.69 \\
\hline 2 & Hand swab & - & 130 & - & - & \\
\hline 3 & Hand swab & 410 & - & - & - & \multirow{2}{*}{51.22} \\
\hline 4 & Hand swab & - & 200 & - & - & \\
\hline 5 & Hand swab & - & - & 140 & - & \multirow{2}{*}{100.00} \\
\hline 6 & Hand swab & - & - & - & $<10$ & \\
\hline 7 & Hand swab & - & - & 1100 & - & \multirow{2}{*}{90.91} \\
\hline 8 & Hand swab & - & - & - & 100 & \\
\hline
\end{tabular}


Jegannathan Ganesan et.al., Anti-Microbial Efficacy of CO-AYUR Steam against Emerging diseases

\begin{tabular}{|c|c|c|c|c|c|c|}
\hline 9 & Hand swab & 190 & - & - & - & \multirow{2}{*}{89.47} \\
\hline 10 & Hand swab & - & 20 & - & - & \\
\hline 11 & Surface swab & 50 & - & - & - & \multirow{2}{*}{100} \\
\hline 12 & Surface swab & - & $<10$ & - & - & \\
\hline 13 & Surface swab & 260 & - & - & - & \multirow{2}{*}{76.92} \\
\hline 14 & Surface swab & - & 60 & - & - & \\
\hline 15 & Surface swab & - & - & 70 & - & \multirow{2}{*}{57.14} \\
\hline 16 & Surface swab & - & - & - & 30 & \\
\hline 17 & Surface swab & - & - & 80 & - & \multirow{2}{*}{62.50} \\
\hline 18 & Surface swab & - & - & - & 30 & \\
\hline
\end{tabular}

Table 6: Day 3 - Microbial load in the swab samples and the percentage reduction

\begin{tabular}{|c|c|c|c|c|c|c|}
\hline \multirow{3}{*}{ S . NO. } & \multirow{3}{*}{ Type of Swab } & \multicolumn{4}{|c|}{ Microbial load (Before and after disinfection, CFU/swab) } & \multirow{3}{*}{$\begin{array}{l}\text { Microbial load } \\
\text { Reduction \% }\end{array}$} \\
\hline & & \multicolumn{2}{|c|}{$20 \mathrm{sec}$} & \multicolumn{2}{|c|}{$40 \mathrm{sec}$} & \\
\hline & & Before & After & Before & After & \\
\hline 1 & Hand swab & 50 & - & - & - & \multirow[b]{2}{*}{80.00} \\
\hline 2 & Hand swab & - & 10 & - & - & \\
\hline 3 & Hand swab & 70 & - & - & - & \multirow{2}{*}{71.43} \\
\hline 4 & Hand swab & - & 20 & - & - & \\
\hline 5 & Hand swab & - & - & 250 & - & \multirow{2}{*}{100.00} \\
\hline 6 & Hand swab & - & - & - & $<10$ & \\
\hline 7 & Hand swab & - & - & 8400 & - & \multirow{2}{*}{78.57} \\
\hline 8 & Hand swab & - & - & - & 1100 & \\
\hline 9 & Hand swab & 190 & - & - & - & \multirow{2}{*}{89.47} \\
\hline 10 & Hand swab & - & 20 & - & - & \\
\hline 11 & Surface swab & 40 & - & - & - & \multirow{2}{*}{100} \\
\hline 12 & Surface swab & - & $<10$ & - & - & \\
\hline 13 & Surface swab & 30 & - & - & - & \multirow{2}{*}{100} \\
\hline 14 & Surface swab & - & $<10$ & - & - & \\
\hline 15 & Surface swab & - & - & 100 & - & \multirow{2}{*}{60} \\
\hline 16 & Surface swab & - & - & - & 40 & \\
\hline 17 & Surface swab & - & - & 20 & - & \multirow{2}{*}{100} \\
\hline 18 & Surface swab & - & - & - & $<10$ & \\
\hline
\end{tabular}

The results from the analysis of swab samples (hand swab and surface swab) collected for the estimation of Total plate Count showed that there is a reduction in microbial load when exposed to the Steam generated by Pressurized Steam Chamber (PSC) at both the time intervals, 20 and 40 seconds.

Table 7: The percent reduction of TPC at 20 and 40 seconds

\begin{tabular}{|c|c|c|c|c|c|c|}
\hline Samples & \multicolumn{3}{|c|}{ \% Reduction@20s } & \multicolumn{3}{|c|}{ \% Reduction@40s } \\
\hline \multirow{6}{*}{ Hand swab } & Day 1 & Day 2 & Day 3 & Day1 & Day2 & Day3 \\
\hline & 34.78 & 78.69 & 80.00 & 50.00 & 100.00 & 100.00 \\
\hline & 58.82 & 51.22 & 71.43 & 30.77 & 90.91 & 78.75 \\
\hline & 40.00 & 89.47 & - & - & - & - \\
\hline & \multicolumn{3}{|c|}{ Reduction range $=34.78 \%-89.47 \%$} & \multicolumn{3}{|c|}{ Reduction range $=30.77 \%-100.00 \%$} \\
\hline & \multicolumn{3}{|c|}{ Average percent reduction $=63.05$} & \multicolumn{3}{|c|}{ Average percent reduction $=75.04$} \\
\hline \multirow{4}{*}{ Surface swab } & 100.00 & 100.00 & 100.00 & 51.52 & 57.14 & 60.00 \\
\hline & 46.67 & 76.92 & 100.00 & 100.00 & 62.50 & 100.00 \\
\hline & \multicolumn{3}{|c|}{ Reduction range $=46.67 \%-100 \%$} & \multicolumn{3}{|c|}{ Reduction range $=51.52 \%-100 \%$} \\
\hline & \multicolumn{3}{|c|}{ Average percent reduction $=87.26$} & \multicolumn{3}{|c|}{ Average percent reduction $=71.86$} \\
\hline
\end{tabular}

The results from the hand swabs collected before and after the exposure time of $20 \mathrm{sec}$, the percent reduction in the TPC ranged from 34.78\% $89.47 \%$ with an average reduction of $63.05 \%$ was observes. The results from the hand swabs collected before and after the exposure time of $40 \mathrm{sec}$., show the percent reduction in the TPC ranged from $30.77 \%$ - $100.00 \%$ with an average reduction of $75.04 \%$.
Protocol for Efficacy evaluation of Pressurized Steam Chamber (PSC) In MSME

\section{Fungus and bacteria}

1. Sanitizing against fungus and bacteria was checked in the interval of 20 and 30 seconds.

2. Developed Fungus and bacteria plates were placed in PSDC-6 with the above- mentioned intervals.

3. Sanitized plates after completion of the incubation were re-incubated to measure the effectiveness of steaming. 
4. Results was recorded in log reduction with observed fungal and bacterial growth.

MSME report reveals that there is a significant inhibition in bacteria and fungus in time-dependent manner.

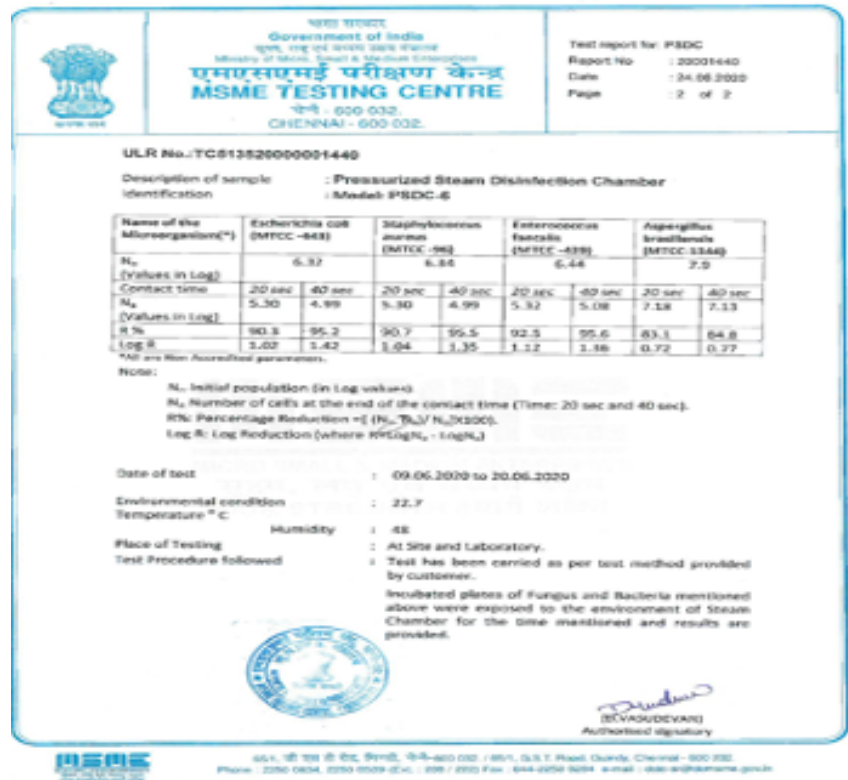

\section{Conclusion}

Based upon our conducted study we conclude that essential phytotherapeutic oils with steam could be used as effective disinfectants in any public and private sector to control respiratory tract infection and improve the relief of symptomatic patients, due to their anti-bacterial and anti-viral activity, which was observed at optimized vapour phase condition in the pressurized disinfectants.

\section{Conflict of interests} interest.

The authors declare that there is no conflict of

\section{Acknowledgments}

The author would like to thank the Managing Director (Jegannathan .G) of Ideal Flow Control Private Limited who had given great support to this project.

\section{References}

1. Cascella M, Rajnik M, Cuomo A, et al. 2020. Features, Evaluation, and Treatment of Coronavirus. Stat Pearls. NCBI.

2. Sunlight, Heat And Humidity Weaken Coronavirus: US Official https://www.businessleague.in/ 2020/04/24/sunlight-heat-and-humidity-weakencoronavirus-us-official.

3. Coronavirus in Mumbai: Study shows positive results via steam therapy on asymptomatic and symptomatic patients By Swapnil Mishra.

4. Steam Sterilization Guideline for Disinfection and Sterilization in Healthcare Facilities (2008)

5. Enforcement Policy for Sterilizers, Disinfectant Devices, and Air Purifiers During the Coronavirus Disease 2019 (COVID-19) Public Health Emergency.

6. Horvath $G$ and Ács K. "Essential oils in the treatment of respiratory tract diseases highlighting their role in bacterial infections and their antiinflammatory action: a review' Flavour Frag. J.2014; 30 : 331-341. https://doi .org/ 10.1002/ ffj. 3252 .

7. Pirtle E.C. and Beran G.W., 'Virus survival in the environment' Rev. Sci. Tech. 1991; 10 (3) : 733-748. https://doi.org/10.20506/rst.10.3.570.

8. Moghadamtousi S. Z., Khadir H. A., Hassandarvish P., Tajik H., Abubakar S. 'A Review on Antibacterial, Antiviral, and Antifungal Activity of Curcumin'. Bio. Med . Res. Int., 2014; 64 : 1-12. https://doi.org/10.1155/2014/186864.

9. Ong G.H. Syamsiah A.S., Hasrul A.H., Maizatul Z., Jihan R., 'Antiviral Effect Of Aqueous Neem Extract From Branches Of Neem Tree On New Castle disease virus. Mal. J. Veter. Res., 2014; 5(2): 5-9. 